\title{
Comment on Maravelis et al. “Accretionary prism-forearc interactions as reflected in the sedimentary fill of southern Thrace Basin (Lemnos Island, NE Greece)”
}

\author{
L. Caracciolo ${ }^{1}$, G. Meinhold ${ }^{2}$, S. Critelli ${ }^{3}$, H. von Eynatten ${ }^{2}$, P. Manetti ${ }^{4}$ \\ ${ }^{1}$ Chemostrat, Sandtrak Unit, Buttington Park, Welshpool SY21 8SL, UK \\ ${ }^{2}$ Abteilung Sedimentologie/Umweltgeologie, Geowissenschaftliches Zentrum der Georg- \\ August-Universität Göttingen, Göttingen, Germany \\ ${ }^{3}$ Dipartimento di Biologia, Ecologia e Scienze della Terra (DIBEST), Università della \\ Calabria, via P. Bucci, cubo 4b, Rende, CS, Italy \\ ${ }^{4}$ Dipartimento di Scienze della Terra, Università degli Studi di Firenze, Florence, Italy
}

Corresponding author: luca.caracciolo@unical.it (L. Caracciolo)

This contribution is intended to shed light on the content of the paper by Maravelis et al. (2015) about the evolution of the island of Limnos, a small portion of the Cenozoic Thrace Basin (Turkey, Greece and Bulgaria). Although we appreciate their approach to use sediment provenance for paleotectonic reconstructions, we have concerns how this subject has been dealt with and how it is presented to the scientific community. Most of our criticism is about the attempt of Maravelis et al. to provide a review of the evolution of the Thrace Basin using (1) an inadequate dataset, (2) an inadequate area (Limnos is $<5 \%$ of the Thrace Basin) and (3) the interpretation provided by different authors in previous papers without properly citing the source of the information. In their introduction section, Maravelis et al. (2015) summarise the results from previous provenance studies done in the whole Thrace Basin (extending through Greece, Bulgaria and Turkey). Interestingly, they do not mention the work by Meinhold and BouDagher-Fadel (2010) and Caracciolo et al. (2012) for the EoceneOligocene successions exposed on the island of Samothraki (NE Greece) and in Southern Bulgaria, respectively.

Furthermore, it was a surprise to recognise that Maravelis et al. (2015) did not even mention the Reply of Caracciolo et al. (2013) to their discussion (Maravelis and Zelilidis 2013a, b, cited in Maravelis et al. 2015) where key problems about the provenance of the Thrace Basin sediments were debated. How should this issue be evaluated objectively, when Maravelis et 
al. (2015) use the evidences provided by Caracciolo et al. (2013) to support part of the provenance aspects included in their 2015 paper without referring to the original sources? Here we like to point out that Caracciolo et al. (2013) highlighted that Maravelis and Zelilidis (2010) have never recognised the occurrence of (1) glaucophane schists, nor of (2) picotite, a term used in d'Atri et al. (2012) for detrital Cr-spinel. Moreover, Maravelis and Zelilidis (2010) mentioned only a minor influx of volcanic material, but volcanic detritus is widely documented by other authors (Caracciolo et al. 2011, 2012; d'Atri et al. 2012; Cavazza et al. 2014). These data are mingled in the Maravelis et al. (2015) "Provenance" section, where the authors, for instance, falsely cite Caracciolo et al. (2011) as evidence for the scarcity of volcanic material. Conversely, the latter authors have demonstrated the dominance of volcanic lithic fragments, as shown in an Lm-Lv-Ls ternary diagram included in the respective paper (Fig. 6c in Caracciolo et al. 2011). The incorrect use of all these informations and the insufficient credit given to the results from other authors lead to a manipulation of the conclusions provided by Caracciolo et al. (2011, 2013), d’Atri et al. (2012) and Cavazza et al. (2014). Another point of discussion is related to both the analytical techniques and the "provenance" diagrams used by Maravelis et al. (2015). In particular, we refer to the use of hand-held XRF to determine the chemical data used for their interpretation. It is well known that measurement accuracy of hand-held XRF has limitations and needs a very good calibration and careful interpretation. Even so, determination of $\mathrm{Cr}$ is subject to a minimum error ranging between 5 and $15 \%$ (according to our experience at Chemostrat Ltd.) depending on the quality of calibration. Error margins in provenance studies are a critical issue and normally are strictly checked by reviewers to validate the quality of the final interpretation. Maravelis et al. (2015) analysed 20 mudstone samples by hand-held XRF and used the major and trace element data for provenance interpretation. We do not go into the details for each element and diagram but rather highlight two striking issues:

- Two mudstone samples have Ni values of zero (see Table 1 in Maravelis et al. 2015), which is rather strange since the $\mathrm{Cr}$ values of these samples are above $300 \mathrm{ppm}$. Either there was a problem with the hand-held XRF or it is simply a typo in the data table. In siliciclastic sedimentary rocks, Cr values higher than those typical for average continental crust (150 ppm Cr: Rudnick and Gao 2003) typically correlate with elevated Ni values and vice versa (e.g. Figure 3 in Garver et al. 1996; Fig. 17 in Meinhold et al. 2009; Fig. 14 in Hofer et al. 2013). 
- Maravelis et al. (2015, p. 1050) recognised “a marked positive $\mathrm{CaO}$ anomaly”, which they used together with other parameters to suggest a source of mafic (and intermediate) composition. Although it is out of discussion that mafic (and intermediate) rocks supplied detrital material, the use of $\mathrm{CaO}$ content of mudstones as one of the arguments is highly debatable since $\mathrm{CaO}$ is in such settings more likely related to the depositional environment and diagenesis rather than provenance.

Regardless, which provenance model other workers are going to follow, we want to express our respect for the research that has been and is still going on in the Thrace Basin.

\section{References}

Caracciolo L, Critelli S, Innocenti F, Kolios N, Manetti P (2011) Unraveling provenance from Eocene-Miocene sandstones of the Thrace Basin, NE Greece. Sedimentology 58:19882011

Caracciolo L, von Eynatten H, Tolosana-Delgado R, Critelli S, Manetti P, Marchev P (2012) Petrological, geochemical, and statistical analysis of Eocene-Oligocene sandstones of the western hrace Basin, Greece and Bulgaria. J Sediment Res 82:482-498

Caracciolo L, Critelli S, Innocenti F, Kolios N, Manetti P (2013) Reply to the discussion by Maravelis and Zelilidis on "Unravelling provenance from Eocene-Oligocene sandstones of the Thrace Basin, North-east Greece” by Caracciolo et al. (2011). Sedimentology 60:865-869

Caracciolo L, Critelli S, Cavazza W, Meinhold G, von Eynatten H, Manetti P (2015) The Rhodope Zone as a primary sediment source of the southern Thrace basin (NE Greece and NW Turkey): evidence from detrital heavy minerals and implications for centraleastern Mediterranean palaeogeography. Int J Earth Sci 104:815-832

Cavazza W, Caracciolo L, Critelli S, d’Atri A, Zuffa GG (2014) Petrostratigraphic evolution of the Thrace Basin (Bulgaria, Greece, Turkey) within the context of Eocene-Oligocene post-collisional evolution of the Vardar-I'zmir-Ankara suture zone. Geodin Acta 26(12):12-26. doi:10.1080/09853111.2013.858943

d'Atri A, Zuffa GG, Cavazza W, Okay AI, Di Vincenzo G (2012) Detrital supply from subduction/accretion complexes to the Eocene-Oligocene post-collisional southern Thrace Basin (NW Turkey and NE Greece). Sediment Geol 243-244:117-129 
Garver JI, Royce PR, Smick TA (1996) Chromium and nickel in shale of the Taconic foreland: a case study for the provenance of fine-grained sediments with an ultramafic source. J Sed Res 66:100-106

Hofer G, Wagreich M, Neuhuber S (2013) Geochemistry of fine-grained sediments of the upper Cretaceous to Paleogene Gosau Group (Austria, Slovakia): implications for paleoenvironmental and provenance studies. Geosci Front 4:449-468

Maravelis A, Zelilidis A (2010) Petrography and geochemistry of the late Eocene-early Oligocene submarine fans and shelf deposits on Lemnos Island, NE Greece: implications for provenance and tectonic setting. Geol J 45:412-433

Maravelis A, Zelilidis A (2013a) Discussion: unravelling provenance from Eocene-Oligocene sandstones of the Thrace Basin, Northeast Greece” by Caracciolo et al. (2011). Sedimentology 58:1988-2011

Maravelis A, Zelilidis A (2013b) Discussion: unravelling provenance from Eocene-Oligocene sandstones of the Thrace Basin, Northeast Greece” by Caracciolo et al. (2011). Sedimentology 60:860-864

Maravelis AG, Pantopoulos G, Tserolas P, Zelilidis A (2015) Accretionary prism-forearc interactions as reflected in the sedimentary fill of southern Thrace Basin (Lemnos Island, NE Greece). Int J Earth Sci 104:1039-1060

Meinhold G, BouDagher-Fadel MK (2010) Geochemistry and biostratigraphy of Eocene sediments from Samothraki Island, NE Greece. N Jahrb Geol Paläont Abh 256:17-38

Meinhold G, Kostopoulos D, Reischmann T, Frei D, BouDagher-Fadel MK (2009) Geochemistry, provenance and stratigraphic ge of metasedimentary rocks from the eastern Vardar suture zone, northern Greece. Palaeogeogr Palaeoclimatol Palaeoecol 277:199-225

Rudnick RL, Gao S (2003) Composition of the continental crust. In: Holland HD, Turekian KK (eds) Treatise on geochemistry. Elsevier-Pergamon, Oxford, pp 1-64 